\title{
Detection and quantification of Xanthomonas axonopodis pv. phaseoli and its variant fuscans in common bean seeds ${ }^{1}$
}

\author{
Norimar D’Ávila Denardin²*, Vanessa Andréia Agostini²
}

\begin{abstract}
The common bacterial blight of common beans (CBCF), a disease caused by Xanthomonas axonopodis pv. phaseoli (Xap) and Xanthomonas axonopodis pv. phaseoli var. fuscans (Xapf), significantly reduces grain yield and seed quality. Because this bacterium is mainly disseminated through infected seeds, efficient detection of Xap and Xapf is important to assure the productivity and quality of the crop. In this study, various techniques that included different extraction techniques (two different incubation times, with and without centrifugation) and five culture media (Kado 523, GYCA, MXP, NSA, and PTSA) were tested for the detection of the seed-borne inoculum, using three different seed samples. Overnight incubation of the seeds, followed by centrifugation and incubation in Kado 523 resulted in higher extraction of Xap and Xapf. The best extraction technique was overnight incubation followed by centrifugation, and the best medium was PTSA. Among the tested culture media, PTSA provided better identification and counting of the bacterial colonies, thus allowing the quantification of the seed infection levels.
\end{abstract}

Index terms: seed pathology, bacterial extraction, culture media, dry beans.

\section{Detecção e quantificação de Xanthomonas axonopodis pv. phaseoli em sementes de feijoeiro comum}

\begin{abstract}
RESUMO - O crestamento bacteriano comum do feijoeiro (CBCF), incitado pela bactéria Xanthomonas axonopodis pv. phaseoli (Xap) e sua variante fuscans, é responsável pela qualidade da semente e por considerável redução no rendimento da cultura, sendo a principal fonte primária desse patógeno, contribuindo para sua sobrevivência e disseminação. O objetivo deste trabalho foi avaliar a eficiência de métodos de extração e de meios de cultura, para os processos de detecção e de quantificação de Xap e Xapf em sementes de feijoeiro comum (Phaseolus vulgaris L.), que sejam sensíveis, rápidos e econômicos para análise laboratorial de rotina. Compararam-se quatro técnicas de extração e o desempenho de cinco meios de cultura, empregando-se amostras de sementes de dois cultivares de feijoeiro, cultivados em duas safras. Os métodos de extração foram constituídos por dois tempos de incubação, com e sem centrifugação, associados aos meios de cultura 523 Kado e MXP. O desempenho dos meios de cultura envolveram 523 Kado, MXP, GYCA, NSA e PTSA. O melhor método de extração foi a incubação por uma noite, seguida de centrifugação, e o meio de cultura de melhor desempenho foi o PTSA, por facilitar a identificação e a enumeração de colônias típicas de Xap e Xapf e permitir a determinação de diferenças nos níveis de infecção nas amostras de semente estudadas.
\end{abstract}

Termos para indexação: patologia de sementes, meio de cultura, Phaseolus vulgaris, bactéria.

\section{Introduction}

The common bacterial blight of bean (CBCF), incited by Xanthomonas axonopodis pv. phaseoli (Xap) (Smith) Vauterin et al. (1995) and by its variant fuscans (Xapf), described by Burkholder and Bullard (1946), is characterized as a disseminated disease in most regions that produce beans (Phaseolus vulgaris L.) in the world (Albuquerque et al., 2011; Alavi et al., 2008; Saettler, 1991; Gilbertson, 1994; Sartorato and Rava, 1994; Bianchini et al., 2005) being considered as quarantine pathogen in countries such as the United States, Croatia and countries of the European and Mediterranean Organization for Plant Protection (EPPO).

Xanthomonas is a genus that includes numerous phytopathogenic species, characterized by a narrow range of hosts. However, members of this genus are able to infect a wide variety of plants, distributed among the monocotyledonous and dicotyledonous plant species.

From a contaminated seed (main focus), bacteria can colonize the surface of the tissues of the shoot (epiphytic

Submitted on 12/03/2012. Accepted for publication on 09/26/2013.

${ }^{2}$ Departamento de Microbiologia e Fitopatologia, Universidade de Passo Fundo, Caixa Postal 611, 99001-970 - Passo Fundo, RS, Brasil.

*Corresponding author: <norimar@upf.br> 
development), or may invade emerging seedlings (endophytic development). $X$. axonopodis pv. phaseoli is particularly well adapted for epiphytic survival in the phyllosphere because it is able to aggregate into biofilms that protect against environmental stresses. Symptoms appear when environmental conditions are favorable (high relative humidity and warm temperature) and when their population sizes are sufficient (106 cfu/g fresh weight).

The seed is the main source of primary inoculum of this pathogen (Velásquez and Trujillo, 1984), which contributes to its survival, spread and reduced productivity from $10-70 \%$ under conditions of natural incidence mainly in temperate climates. The $X$. axonopodis pv. phaseoli and var. fuscans can survive epiphytically in the phyllosphere forming biofilms that protect against environmental stresses. Symptoms of the disease appear when relative humidity and temperature are favorable and when the cell population reaches $10^{6} \mathrm{ufc}^{-1}$ fresh weight of tissue (Darrasse, et al., 2007) The control of this pathogen is based on the use of certified seeds, crop rotation, resistant varieties, host weed management, biological control, and more recently, on the induction of resistance.

The health test of representative samples from seed lots is aimed at determining the quality of seeds, providing subsidies for certification and inspection of seeds, ensuring marketing and seeding (Machado, 2000) and facilities for tracking problems that occurred and the prevention of future storage and cultivation field problems. In Brazil, the analysis of the presence of Xap and its variant Xapf in seeds of common bean is based on Ordinance No. 3 of January 5th, 2004, by the Ministries of Agriculture, Livestock and Supply (MAPA), which considers this bacterium as a non regulated quarantine pest, endowed with zero tolerance for its presence in seed lots.

When establishing seed quality standards, it must be ensured that the levels proposed are compatible with the production technology and environmental conditions in order to avoid a collapse in both production and distribution of seeds. It is this measure that regulates the production of seeds and establishes the competition and distribution of seeds, ensuring the sustainability of the seed business.

The methods for detecting bacteria in seeds must be reproducible, economical, fast (Schaad et al., 2001) and of high sensitivity (Rat, 1988). Several methods have been developed and are available, some being highly sensitive for the detection and identification of this bacteria, such as serology, molecular techniques and flow cytometry (Sheppard et al., 2013; Popovic et al., 2010; Tebaldi et al., 2010; Torres et al., 2009; Tebaldi et al., 2007; Remeeus and Sheppard, 2006; Maringoni et al., 1994; Valarini and Menten, 1992; Van-Vuurde et al., 1983). However, these procedures are not yet available in most laboratories, because they require sophisticated equipment, high costs and, mainly, require specialized training for analysts. Thus, the method which employs sowing extract or seed in semiselective culture media are capable of providing growth and quantification of this bacteria, enabling to verify its presence and viability (Chang et al., 1991).

The choice of extraction technique for Xap and its variant Xapf in the seed is essential for successful detection, for they may be located externally and/or internally to the seed (VanVuurde, 1987). Thus, the combination of an efficient extraction method with a semi-selective culture medium is a valuable contribution to the investigation of this pathogen in seeds.

This study aimed to evaluate extraction methods and efficiency of culture media for the processes of detection and quantification of Xap and its variant Xapf in common bean seeds.

\section{Materials and Methods}

The seeds used were derived from seed production crops of the common bean, cultivar FT Bio Nobre and cultivar BRS Valente, from the northern region of the State of Rio Grande do Sul, harvests 2002/2003 and 2003, provided by Cooperativa Tritícola de Erechim Ltda. (COTREL) and acquired from EMBRAPA. For each cultivar and harvest, were received three samples of $25 \mathrm{~kg}$ of seeds each.

The treatments, aiming to extract Xanthomonas axonopodis pv. phaseoli (Xap) and its variant fuscans (Xapf) from bean seeds, were formed by four techniques: a) a one hour incubation without centrifugation; b) a one hour incubation with centrifugation; c) incubation overnight $( \pm 18$ hours) without centrifugation; and d) incubation overnight ( \pm 18 hours) with centrifugation.

\section{Essay I - Extraction of Xap and Xapf of common bean seeds}

Sample preparation: Seeds of the cultivar FT Bio Nobre were subjected to surface disinfection by immersion in $70{ }^{\circ} \mathrm{GL}$ alcohol for five minutes, followed by immersion in sodium hypochlorite at $1 \%$ for three minutes and six successive washes in sterile distilled water. Next, the seeds were transferred to a sterile Erlenmeyer and immersed in 500 $\mathrm{mL}$ of sterile saline phosphate buffer solution (SPBS). The seeds, thus prepared, were subjected to four treatments for Xap and Xapf extraction.

For each extraction technique a sample of 1,000 seeds was used, divided into four subsamples of 250 seeds, which constituted the essay replications.

The techniques used were: a) Extraction Technique 1: the samples were incubated for one hour with stirring at $120 \mathrm{rpm}$ 
and $4{ }^{\circ} \mathrm{C}$ and then brought to the laminar flow hood. From the suspension obtained, two aliquots of one $\mathrm{mL}$ each were taken, then transferred to two test tubes containing $9 \mathrm{~mL}$ of SPBS each. Next, two series of successive dilutions were undertaken, one for each test tube, comprising five dilution units for each series. Then, an aliquot $500 \mu \mathrm{L}$ of each dilution factor was sown in triplicate, including the dilution factor $10^{\circ}$, in the culture medium 523 (Kado and Heskett, 1970) and MXP (Claflin et al., 1985), through the spread technique, using a Drigalski handle (spread plate). After sowing, the cultures were maintained in a bacteriological incubator at $28{ }^{\circ} \mathrm{C}$ for 48 and 96 hours;

b) Extraction Technique 2: Samples were prepared as in "Extraction Technique 1", however, in the laminar flow hood, the suspension was poured into sterile tubes with adequate caps for centrifugating, proceeding to centrifugation (centrifuge Excelsa Baby II model R-206) at $3,000 \mathrm{x}$ g for 30 minutes. After centrifugation, in a laminar flow hood, the supernatant was removed and the pellet was resuspended with $3 \mathrm{~mL}$ SPBP. From this suspension, the same steps from "Extraction Technique 1" were repeated; c) Extraction Technique 3: The samples were incubated overnight $( \pm 18 \mathrm{~h})$ at $4{ }^{\circ} \mathrm{C}$ under orbital shaking at 120 $\mathrm{rpm}$, then following the same procedures from "Extraction Technique 1"; d) Extraction Technique 4: the samples were incubated overnight $( \pm 18 \mathrm{~h})$ and at $4{ }^{\circ} \mathrm{C}$, under orbital agitation at $120 \mathrm{rpm}$, then following the same procedures from "Extraction Technique 2".

Evaluation of extraction techniques of Xap and Xapf from the seeds: the efficiency of extraction techniques was determined by observation of the growth of colony forming units (CFU) typical of Xap Xapf, of pale yellow color or with melanoid pigment diffused into the culture medium. The identity of these colonies was confirmed by pathogenicity and hypersensitivity reaction tests comparing them to the isolated "Type" bacteria IB1190-95, from the collection of Phytobacteria from the Biological Institute, Experimental Station of Campinas. The quantification of $\mathrm{CFU}$ was processed from the calculation: dilution factor $\mathrm{x}$ volume $(\mathrm{mL})$ $x$ number of typical CFU grown in the two culture media used in the four extraction techniques. The counting was performed only in Petri plates corresponding to the dilution factors presenting from 30 to 300 typical CFU. In order to ensure the identification of typical Xap and Xapf colonies obtained from common bean seeds, in parallel with the essay, "Type" bacteria, isolated IB1190-95, was grown in each of the culture media, with the same dilution series. Was considered as the best extraction method which had the highest number of typical CFU. $\mathrm{mL}^{-1}$ in the shortest incubation time.

\section{Essay II - Performance of the culture media}

The treatments consisted of five culture media: 523 (Kado and Heskett, 1970), GYCA (Saettler, 1971), NSA (Schaad and Stall, 1988), PTSA (Van-Vuurde et al., 1983) and MXP (Claflin et al., 1985). For comparison of the media, were used three samples of common bean cultivars seeds: a) cultivar Bio FT Nobre, 2002/2003 harvest; b) cultivar Bio FT Nobre, 2003 harvest; and c) cultivar BRS Valente, 2003 harvest.

Preparation of samples: The samples were prepared as in Essay I, Extraction of Xap and Xapf from common bean seeds, and the extraction technique chosen for this essay corresponded to "Extraction Technique 4", i.e. incubation overnight ( \pm 18 hours) with centrifugation. From the resuspension of the pellet, in three series of successive dilutions were made, following the method described in Extraction Technique 1. Then, an aliquot of $200 \mathrm{~mL}$ of each dilution factor was sown in triplicate, including the factor $10^{\circ}$, in the five culture media, through the spread technique, using a Drigalski handle (spread plate). After sowing, the cultures were maintained in a bacteriological incubator at $28^{\circ} \mathrm{C}$ for 48 and 96 hours, except for the medium MXP, which remained in incubation during 15 days. The performance of the culture media was evaluated by counting the typical CFU of Xap and Xapf in each culture medium. This counting was performed only in Petri plates corresponding to the dilution factors presenting from 30 to 300 typical CFU. In order to ensure the identification of typical Xap and Xapf colonies obtained from common bean seeds, in parallel with the essay, "Type" bacteria, isolated IB1190-95, was grown in each of the culture media, with the same dilution series. The performance of culture media on the efficiency of the processes of detection and quantification of Xap and Xapf was determined by considering the degree of selectivity, complexity level and nutrient requirement for the preparation of the medium, economy and detection sensitivity by means of number of typical $\mathrm{CFU}$, the latter being determined by the ratio of cells recovered.

Essay III - Characterization of Xapf and Xap isolates obtained from bean seeds

The isolates obtained from essays I and II were transferred and purified by seeding in streaks, in medium 523 (Kado and Heskett, 1970) and PTSA (Van-Vuurde et al., 1983) for growing and obtaining isolated colonies. After 48 hours of incubation, we evaluated the morphological, physiological, biochemical and staining (Gram staining) characteristics, according to Schaad et al. (2001), as well as application of Koch's postulates, inoculating plants of common bean and tobacco for observation of pathogenicity and hypersensitivity 
reaction (Schaad et al., 2001). The identity of the isolates was confirmed by the Biolog Kit ${ }^{\circledR}$ (Biolog ID Characterization).

\section{Experimental design and data analysis}

Extraction techniques and culture media constituted a completely randomized design. For the extraction techniques there were four treatments in four replicates, and means were calculated from two culture media, two series of dilution and plating in triplicate. For the performance of culture media, there were five culture media, three sources of bean seeds in four replicates and three series of dilution and plating in triplicate. The results obtained for the two trials were subjected to analysis of variance $(\mathrm{P}<0.05)$ through the statistical package available in the software SAS, version 6.12 for Windows. The data obtained were transformed into $\log \mathrm{x}$ for analysis of variance and the treatment means were compared by Tukey's test at 5\% probability.

\section{Results and Discussion}

\section{Essay I - Extraction Technique of Xap from the seeds}

The extraction techniques showed significant differences between them. It is observed in Table 1 that the extraction technique by incubating the seeds overnight in sterile saline phosphate buffer solution (SSPBS), followed by centrifugation of the suspension, was the most sensitive, detecting $4 \times 10^{4}$ CFU. $\mathrm{mL}^{-1}$ in culture medium 523 (Kado and Heskett, 1970) and $1 \times 10^{4}$ CFU.mL ${ }^{-1}$ in the medium (Claflin et al., 1985). Without the centrifugation process, was detected $7 \times 10^{3}$ and $3 \times 10^{3}$ CFU.mL $L^{-1}$ respectively for these same media. Maringoni et al. (1994), working with extraction methods of Xap from bean seeds, found mean values of $2,49 \times 10^{4}$ CFU.mL ${ }^{-1}$ for the maceration and incubation technique during 24 hours at $5{ }^{\circ} \mathrm{C}$. The results obtained by these authors, using more laborious techniques were similar to those found in this study. The technique using a 1 hour incubation with centrifugation was effective only when using the culture medium 523 (Kado and Heskett, 1970) $\left(5 \times 10^{3} \mathrm{~mL}^{-1}\right)$. After 96 hours of incubation, the colonies presented in smaller numbers, while for the medium MXP (Claflin et al., 1985) there was no growth in this incubation period. For the technique using 1 hour of incubation without centrifugation, there was no growth for both culture media employed, both for evaluation after 96 hours and after 12 days in MXP (Claflin et al., 1985), whose period indicated for CFU appearance in this medium is from 7 to 12 days of incubation. It can be verified, thus, that the MXP medium is not a sensitive culture medium to detect Xap and Xapf.
Table 1. Efficiency of four extraction techniques of Xanthomonas axonopodis pv. phaseoli, in common bean seeds (Phaseolus vulgaris L.), cultivar FT Bio Nobre, assessed by counting CFU.mL $\mathrm{mL}^{-1}$ in two culture media.

\begin{tabular}{|c|c|c|}
\hline \multirow{3}{*}{ Extraction technique } & \multicolumn{2}{|c|}{ Culture medium } \\
\hline & $523^{1}$ & $\mathrm{MXP}^{2}$ \\
\hline & \multicolumn{2}{|c|}{ - - - UFC.mL $\mathrm{mL}^{-1}$ - - } \\
\hline $\begin{array}{l}\text { Incubation overnight with } \\
\text { centrifugation }\end{array}$ & $4 \times 10^{4} \mathrm{a}$ & $1 \times 10^{4} \mathrm{a}$ \\
\hline $\begin{array}{l}\text { Incubation overnight without } \\
\text { centrifugation }\end{array}$ & $7 \times 10^{3} b$ & $3 \times 10^{3} \mathrm{~b}$ \\
\hline $\begin{array}{l}\text { Incubation for one hour with } \\
\text { centrifugation }\end{array}$ & $5 \times 10^{3} \mathrm{c}$ & $0 \mathrm{c}$ \\
\hline $\begin{array}{l}\text { Incubation for one hour without } \\
\text { centrifugation }\end{array}$ & $0 \mathrm{~d}$ & $0 \mathrm{c}$ \\
\hline $\begin{array}{l}523 \text { (Kado and Heskett, 1970) } \\
\text { 'MXP (Claflin et al., 1985) }\end{array}$ & & \\
\hline
\end{tabular}

\section{Essay II - Performance of the culture media}

Figure 1 shows that in all culture media there was a growth of Xap and Xapf, but with statistical difference between them, and it is possible to verify their sensitivity by the levels of infection in different seed samples of the three samples evaluated. The medium PTSA (Van-Vuurde et al., 1983) was statistically superior to the others, with high sensitivity and selectivity, favoring the growth of the pathogen, with $2.9 \mathrm{x}$ $10^{4}$ CFU.mL ${ }^{-1}$ for cultivar FT Bio Nobre, 2002/2003 harvest, $9.9 \times 10^{4}$ CFU.mL ${ }^{-1}$ for cultivar FT Bio Nobre, 2003 harvest, and $9.4 \times 10^{4}$ CFU.mL ${ }^{-1}$ for cultivar BRS Valente, 2003 harvest. With this culture media, colonies of bacteria could easily be enumerated, and identification of the characteristics of the genus Xanthomonas colonies was facilitated as well, with colonies of bright yellow color and convex surface, for Xap, and light brown colored colonies, at first, and intense brown and shiny after a few days, for Xapf (Abd-Alla et al., 2010). In addition to the easy preparation, this culture medium dispenses the use of antibiotics and fungicides, which makes it more economical. Since, in its formulation, the tyrosine amino acid ((S)-2-amino-3-(4-hydroxyphenyl) propanoic acid) is added, which stimulates the production of the melanine pigment by Xapf, this pigment being the result of secretion and oxidation of an acid which is intermediate of the tyrosine metabolism. According to Darsonval et al. (2009) this characteristic is not related to pathogenicity. However, Mutlu et al. (2008) describe the possibility of this variant, fuscans, expressing greater aggressiveness in the progression of the disease. The medium PTSA (Van-Vuurde et al., 1983) is 
listed among the semi-selective culture media recommended by ISTA/ISHI, for Xanthomonas axonopodis pv. phaseoli detection tests (Sheppard et al., 2007; Sheppard et al., 1989).

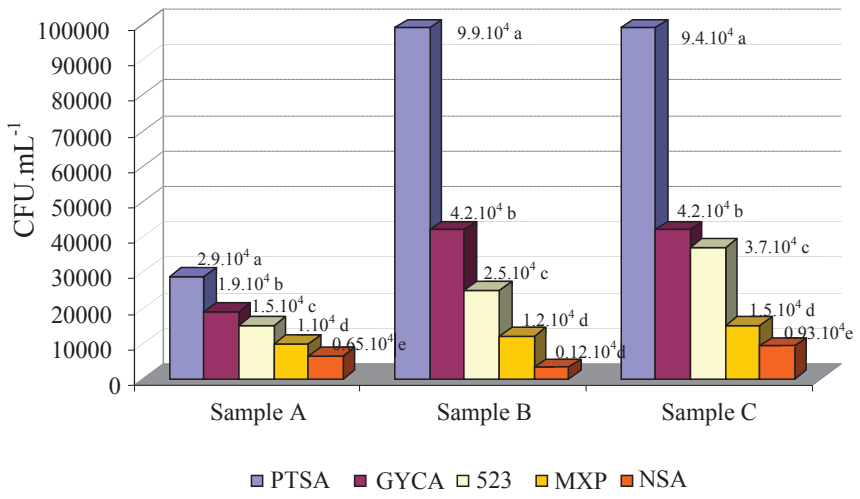

Figure 1. Quantification of colony forming units $\left(\mathrm{CFU} \cdot \mathrm{mL}^{-1}\right)$ of Xanthomonas axonopodis pv. phaseoli and its variant fuscans, in five culture medium, using common bean seeds (Phaseolus vulgaris L.), of two cultivars sown in two seasons in the northern region of Rio Grande do Sul. Obs.: Sample A = cultivar FT Bio Nobre, 2002/2003 harvest; Sample B = cultivar FT Bio Nobre, 2003 harvest; and Sample C = cultivar BRS Valente, 2003 harvest. PTSA (Van-Vuurde et al., 1983); GYCA (Saettler, 1971); 523 (Kado and Heskett, 1970); MXP (Claflin et al., 1985); and NSA (Schaad and Stall, 1988). Means followed by the same letter in each sample do not differ by Tukey's test $(\mathrm{P}<0,05)$.

The media GYCA (Saettler, 1971), 523 (Kado and Heskett, 1970), MXP (Claflin et al., 1985) and NSA (Schaad and Stall, 1988), though allowing the growth of Xap colonies, using the extraction technique through overnight incubation followed by centrifugation, showed colonies in lower amounts and statistically different from the PTSA medium (Van-Vuurde et al., 1983), being less susceptible to detection and recovery, as well as to the identification of Xap.

The colonies showed different aspects in the different culture media evaluated. In the GYCA medium (Saettler, 1971), the colonies showed an intense yellow color, shiny, mucous aspect and convex surface and, for Xapf, after five days, a light brown color. In the medium 523 (Kado and Heskett, 1970), the colonies showed a light yellow color, shiny, mucous aspect and convex surface. After five days, it was observed that the color evolved from light yellow to intense brown, characteristic of Xapf. In the MXP medium (Claflin et al., 1985), it was not possible to observe the presence of the melanin pigment produced by Xapf. In this medium, the colonies showed a lemon-yellow color, making it difficult to differentiate between colonies of Xap and Xapf. In the NSA culture medium (Schaad and Stall, 1988), the colonies showed a light yellow color, mucous and fluid aspect. In the PTSA medium (Van-Vuurde et al., 1983), it was possible to easily differentiate Xap colonies from its variant fuscans, because they produced colonies of beige-brown color surrounded by a halo of diffuse intense brown staining in the middle.

According to Figure 1, it was observed that the levels of infection by Xanthomonas axonopodis pv. phaseoli, of cultivars FT Bio Nobre and BRS Valente grown in the 2003 harvest are significantly higher than the level of infection of cultivar FT Bio Nobre, grown in the 2002/2003 harvest. This finding is clearly evidenced by the extraction technique combined with the performance of the culture medium PTSA (Van-Vuurde et al., 1983). For the calculation of the recovery rate of viable cells, the PTSA medium obtained values significantly larger than the other media tested, reaching 99\%. This allows to infer that using this culture medium and the mentioned extration techniques is of great value as a routine laboratorial technique.

\section{Essay III - Characterization of Xapf and Xap isolates obtained from bean seeds}

The colonies with morphology and coloration characteristic of Xanthomonas, selected and isolated in the different culture media, were positive for genus/species/pathovar of Xap or Xapf, because they showed positive for the presence of xanthomonadine, starch hydrolysis, Tween 80 lipolysis, milk proteolysis and acid production from trehalose, glucose, fructose and sucrose. In addition, they presented hypersensitivity in tobacco plants and pathogenicity in common bean plants (cultivar Bio Nobre), and obtained 95\% probability of being classified as Xanthomonas axonopodis pv. phaseoli by the Biolog Identification System ${ }^{\circledR}$ (Biolog ID Characterization). It is note worthy that the Biolog Identification System ${ }^{\circledR}$ is not prepared to separate Xanthomonas axonopodis pv. phaseoli from its variant fuscans.

\section{Conclusions}

Incubation of seeds overnight with centrifugation and the culture media PTSA and GYCA is the set of procedures that stands out for the detection and identification of colonies typical of Xanthomonas axonopodis pv. phaseoli var. fuscans and Xanthomonas axonopodis pv. phaseoli in common bean seeds.

\section{Acknowledgments}

The authors thank Capes for the scholarship granted and 'Cooperativa Tritícula de Erechim Ltda' (COTREL) for the donation of bean seeds. 


\section{References}

ABD-ALLA, M.H.; BASHANDY, S.R.; SCHNWLL, S. Ocurrence of Xanthomonas axonopodis pv. phaseoli, the causal agent of common bacterial blight bisease, on Seeds of Common Bean (Phaseolus vulgaris L.) in Upper Egypt. Folia Microbiologica, v.55, n.1, p.47-52. 2010.

ALBUQUERQUE, P.; CARIDADE, C.M.R.; MARCAL, A.R.S. ; CRUZ, J.; CRUZ, L.; SANTOS, C.L.; MENDES, M.V.; TAVARES, F. Identification of Xanthomonas fragariae, Xanthomonas axonopodis pv. phaseoli, and Xanthomonas fuscans subsp. fuscans with novel markers and using a dot blot platform coupled_with automatic data analysis. Applied and Environmental Microbiology, v.77, n.16, p. 5619-5628, 2011.

ALAVI, S.M.; SANJARI, S.; DURAND, F.; BRIN, C.; MANCEAU, C.; POUSSIER, S. Assessment of the genetic diversity of Xanthomonas axonopodis pv. phaseoli and Xanthomonas fuscans subsp. fuscans as a basis to identify putative pathogenicity genes and a type III secretion system of the SPI-1 family bymultiple suppression subtractive hybridizations. Applied and Environmental Microbiology, v.74, p.3295-3301, 2008.

BIANCHINI, A.; MARINGONI, A.C.; CARNEIRO, S.M.P.G. Doenças do feijoeiro (Phaseolus vulgaris L.). In: KIMATI, H.; AMORIM, L.; REZENDE, J.A.M.; BERGAMIN FILHO, A.; CAMARGO, L.E.A. Manual de Fitopatologia. v.2, 4.ed. p.333-349, 2005.

BURKHOLDER, W.H.; BULLARD, E.T. Varietal suceptibility of beans to Xanthomonas phaseoli var. fuscans. Plant Disease Reporter, v.30, p.446-448, 1946.

CHANG, C.J.; DONALDSON, D.; CROWLEY, M.; PINNOW, D. A new semi-selective medium for the isolation of Xanthomonas campestris pv. campestris from crucifer seeds. Phytopathology, v.81, p.449-453, 1991.

CLAFLIN, L.E.; VIDAVER, A.K.; SASSER, M.M.X.P. A semi-selective medium for Xanthomonas campestris pv. phaseoli. Phytopathology, v.75, p.730-734, 1985.

DARSONVAL, A.; DARRASSE, A.; DURAND, K.; BUREAU, C.; CEBRON, S.; JACQUES, M.A. Adhesion and fitness in the bean phyllosphere and transmission to seed of Xanthomonas fuscans subsp. fuscans. Mol. Plant Microbe Interact, v.22, p.747-757, 2009.

DARRASSE, A.; BUREAU, C.; SAMSON, R.; MORRIS, C.E.; JACQUES, M.A. Contamination of bean seeds by Xanthomonas axonopodis pv. phaseoli associated with low bacterial densities in the phyllosphere under field and greenhouse conditions. Eur. J. Plant Pathol., v.119, p.203-215, 2007

GILBERTSON, R.L. Detection of the bean common blight bacteria, Xanthomonas campestris pv. Phaseoli and X. c. phaseoli var. fuscans, using the polymerase chain reaction. Phytopathology, v.84, p.1185-1192, 1994.

KADO, C.I.; HESKETT, M.G. Selective media for isolation of Agrobacterium, Corynebacterium, Erwinia, Pseudomonas and Xanthomonas. Phytopathology, v.60, p.969-976, 1970.

MACHADO, J.C. Tratamento de sementes no controle de doenças. Lavras: LAPS/UFLA/FAEPE, 2000. 138p.

MARINGONI, A.C.; KIMATI, H.; KUROZAWA, C. Desenvolvimento de meio de cultura semi-seletivo para Xanthomonas campestris pv. phaseoli. Cientifica, v.22, p.277-288, 1994

MUTLU, N.; VIDAVER, A.K.; COYNE, D.P.; STEADMAN, J.R.; LAMBRECHT, P.A.; REISER, J. Differential Pathogenicity of Xanthomonas campestris pv. phaseoli and X. fuscans subsp. fuscans Strains on Bean Genotypes with Common Blight Resistance. Plant Disease, v.92, n.4, 2008. http://apsjournals. apsnet.org/doi/pdf/10.1094/PDIS_92_4_0546.2013. Accessed on: July $12^{\text {th }} 2013$.
POPOVI, T.; BALAZ, J.; NIKOLIC, Z.T.; STAROVIC, M.; GAVRILOVIC, V.M.; GORAN, A.; VASIC, M.A.; ZIVKOVIC, S. Detection and identification of Xanthomonas axonopodis pv. phaseoli on bean seed collected in Serbia. African Journal of Agricultural Research, v.5 n.19, p.2730-2736, 2010. http://www.academicjournals.org/ajar/pdf/

RAT, B. How to use bacteria detection methods in seed pathology routine laboratory. In: NASSER, L.C.; WETZEL, M.M.; FERNANDES, J.M. Seed pathology international advanced course. Brasília: ABRATES, p.103-107, 1988

REMEEUS, P.M.; SHEPPARD, J.W. ISTA Method Validation Reports3, p.1-11, 2006. http://www.seedtest.org/upload/cms/user/ MethodValidationReports20061.pdf.

SAETTLER, A.W. Seedling injection as an aid in identifying bean blight bacteria. Plant Disease Reporter, v.55, p.703-706, 1971.

SAETTLER, A.W. Angular leaf spot. In: HALL, R. Compendium of Bean Diseases. The American Phytopathological Society, p.15-16, 1991

SARTORATO, A.; RAVA, C.A. Principais doenças do feijoeiro comum e seu controle. Brasília: EMBRAPA-SPI, 1994.

SCHAAD, N.W.; JONES, J.B.; CHUN, W. Laboratory guide for identification of plant pathogenic bacteria. 3 ed. 2001,373p.

SCHAAD, N.M.; STALL, L.R.E. Bacteria In: Annual Meeting of the American Phytopathological Society, 76. Ontario, 1984. Inoculum thresholds of seed borne pathogens. Phytopathological Society, 1988, $158 \mathrm{p}$.

SHEPPARD, J.W.; KUROWSKI, C.; REMEEUS, P.M. Detection of Xanthomonas axonopodis pv. phaseoli and Xanthomonas axonopodis pv. phaseoli var. fuscans on Phaseolus vulgaris. International Rules for Seed Testing, p.07-21, 2007

SHEPPARD, J.W.; ROTH, D.A.; SAETTLER, A.W. Detection of Xanthomonas campestris pv. phaseoli in bean. In: Saettler, A.W.; Schaad, N.W.; Roth, D.A. Detection of bacteria in seed and other planting material. p.17-29, 1989

SHEPPARD, J.W.; KUROWSKI, C.; REMEEUS, P.M. International Rules for seed testing, 7-021: Detection of Xanthomonas axonopodis pv. phaseoli and Xanthomonas axonopodis pv. phaseoli var. fuscans on Phaseolus vulgaris. International Seed Testing Association (ISTA), 2013. http://www. seedtest.org/upload/cms/user/7-021.pdf.

TEBALDI, N.D.; SOUZA, R.M.; MACHADO, J.C. Detecção de Xanthomonas axonopodis pv. phaseoli em sementes de feijão em meio de cultura semi-seletivo. Fitopatologia Brasileira, v.32 p.56-58, 2007. http:// www.scielo.br/pdf/fb/v32n1/08.pdf

TEBALDI, N.D.; PETERS, J.; SOUZA, R.M.; CHITARRA, L.G.; VAN DER ZOUWEN, P.; BERGERVOET, J.; VANDER WOLF, J. Detection of Xanthomonas axonopodis pv. phaseoli in bean seeds by flow cytometry, immunostaining and direct viable counting. Trop. plant pathol., v.35, n.4, p.213-222, 2010

TORRES, J.P.; SILVA JÚNIOR, T.A.F.; MARINGONI, A.C. Detecção de Xanthomonas axonopodis pv. phaseoli em sementes de feijoeiro provenientes do Estado do Paraná, Brasil. Summa Phytopathologica, v.35, n.2, p.136-139, 2009.

VALARINI, P.J.; MENTEN, J.O.M. Xanthomonas campestris pv. phaseoli: método para detecção em sementes de feijão. Fitopatologia Brasileira, v.17, p.373-383, 1992.

VAN-VUURDE, J.W.L. Detection seed borne bacteria by immunofluorescence. In: INTERNATIONAL CONFERENCE IN PLANT PATHOGENIC BACTERIA, 6, Maryland, 1985. Proceedings..., Maryland: Martinus Nijhoff, 1987. p. 799-808. 
VAN-VUURDE, J.W.L.; VAN DEN BOVENKAMP, G.W.; BIRNBAUM, Y. Immunofluorescence microscopy and enzyme-linked immunosorbent assay as potential routine test for the detection of Pseudomonas syringae pv. phaseolicola and Xanthomonas campestris pv. phaseoli in bean seed. Seed Science and Technology, v.11, p.547-559, 1983.
VELÁSQUEZ, N.C.; TRUJILlO, G.E. Evaluación de Xanthomonas campestris pv. phaseoli (Smith) Dye, en lotes de semilla de caraota (Phaseolus vulgaris L.) mediante la tecnica combinada del medio semiselectivo e inmunodifusion en gel de agar. Agronomia Tropical, v.34, p.5967, 1984. http://www.redpav-fpolar.info.ve/agrotrop.

VAUTERIN. L.; HOSTE, B.; KERSTERS,K.; SWINGS, J. Reclassification of Xanthomonas. Journal of Systematic Bacteriology, v.45, n.3, p.472-489, 1995. 